IНТЕРМАРУМ: історія, політика, культура. - Вип. 6.

UDC 39(477)

DOI 10.35433/history. 11196

\author{
Stelnykovych Serhii, \\ Doctor of Sciences (History), \\ Professor at the Department of History of Ukraine, \\ Zhytomyr Ivan Franko State University \\ stel-s@ukr.net \\ ORCID: https://orcid.org/0000-0001-9121-8977 \\ ResearcherID: H-5420-2016
}

\title{
THE ETHNOGRAPHIC ACTIVITIES OF NYKANOR DMYTRUK IN THE 1920s-THE LATE 1930s
}

\section{Abstract}

This paper focuses on the activities of Nykanor Dmytruk as an ethnographer in the 1920s - the late 1930s. The study applies general scientific and special historical methods, in accordance with the basic principles of historical research: historicism, scientificity, objectivity, and consistency. The principles of historicism and scientificity help to reconstruct Nykanor Dmytruk's extensive ethnographic research in the context of that time. The principle of objectivity aids in examining the scholar's ethnographic activities, considering objective historical regularities and critical analysis of literary and historical documentation. The principle of consistency serves for building a holistic picture of the researcher's ethnographic activities in the 1920s - the late 1930s. The article adopts the interdisciplinary approach, implemented through the use of terminology and research tools of other social sciences and humanities. This article is the first comprehensive study of Nykanor Dmytruk's research activities, carried out on the extensive source base. The author proves that Nykanor Dmytruk conducted episodic ethnographic studies as a student. His ethnographic research took on a systemic character when the scholar started collaborating with the Ethnographic Commission of the All-Ukrainian Academy of Sciences. Nykanor Dmytruk's ethnographic interests included a wide range of issues relating to the material and spiritual culture of the Ukrainian people. Moreover, the researcher was also concerned with the ethnographic study of the settlements in Zhytomyr region. His research significantly contributed to the development of ethnography in Ukraine during the interwar period. 
INTERMARUM: history, policy, culture. - Issue 6.

Key words: Nykanor Dmytruk, ethnographic research, the Ethnographic Commission of the All-Ukrainian Academy of Sciences, the Volyn Museum of Local History.

Introduction. Ethnography in Ukraine experienced rapid development and afterward actual decline in the interwar period. In the early 1930s, free creative initiatives, specialized ethnographic institutions, and targeted research programs, started with in the policy of Ukrainization, were curtailed; the ideological offensive and repressions began. Nykanor Dmytruk is a well-known Ukrainian ethnographer. In the 1920 s - the late 1930s, he researched the material and spiritual culture of the Ukrainian people. However, despite his significant contribution to the development of ethnography in the 1920s - the late 1930 s, the researcher was subject to oblivion for a long time. Repressed by the communist regime in the times of the "Great Terror» and later rehabilitated during the «Khrushchev Thaw», Nykanor Dmytruk remained unknown and his creative heritage fell out of the scientific discourse until the early 1990 s.

A comprehensive study of the ethnographic activities of Nykanor Dmytruk in historiography is still lacking. Some researchers, including Stepan Muzychenko (Muzychenko, 1990, p. 61-64), Lyubov Garbuzova (ZhMLH. NM. 5656/1-34. P. 36), Mykola Kostrytsya (Kostrytsya, 1997, p. 136-138; Kostrytsya, 2006, p. 149-153), Oksana Ruban (Ruban, 2015, p. 63-64) analysed his activities generally. While other research studies (Oleksandr Vasyanovych (Vasyanovych, 2003, p. 195197), Faina Ryabchykova (Ryabchykova, 2010, p. 3-17), Mykola Bekh (Bekh, 2012, p. 35-40)) characterised Nykanor Dmytruk's activities within a wider historical context. For example, Mykola Kostrytsya considered his work in the context of the Stalin regime political repressions in Zhytomyr region, and Faina Ryabchykova mentioned it within the analysis of the Ethnography Department at the Volyn Museum of Local History in 1920-1931. Although the researchers highlight Nykanor Dmytruk's significant contribution to the development of ethnography and museum studies in the interwar Ukraine, afull study of his ethnographic activities has not been undertaken. 
IНТЕРМАРУМ: історія, політика, культура. - Вип. 6.

The purpose of this research is to carry out a comprehensive study of Nykanor Dmytruk's ethnographic activities in the 1920s - the late 1930s.

Findings and discussion. Nykanor Dmytruk was born on July 26, 1902, in the village Luka, Zhytomyr County (State Archives of Zhytomyr Region. F. R-5013. Op. 2. D. 1336. L. 41), where he spent his childhood and youth. He received an elementary education at a parochial school and in the county two-form secondary school. In 1917 - 1920, Nykanor Dmytruk studied at the Zhytomyr teachers' training college, and later, after a year of military service, at Zhytomyr Higher Pedagogical Courses named after Drahomanov and then at the Volyn Institute of Public Education (IASFE named after M. T. Rylsky of NAS of Ukraine. F. 1-2. D. 58. L. 86). Right about the time he worked as a teacher in Zhytomyr vocational school No. 19 (ZhMLH. RM. 5656/134. L. 33).

During his studies, Nykanor Dmytruk became interested in ethnography. He transferred from the second year at the Volyn Institute of Public Education to Kyiv Archeological Institute, which provided professional training of ethnographers. However, he failed to complete his studies at the Kyiv Archeological Institute was disbanded in 1924 (IASFE named after M. T. Rylsky of NAS of Ukraine. F. 1-2. D. 58. L. 86).

Nykanor Dmytruk started collecting ethnographic materials as a student. He got acquainted with a famous scholar Vasyl Kravchenko, who organized and headed the Ethnography Department at the Volyn Museum of Local History in 1920. The school arinvolved students from Zhytomyr educational institutions in ethnographic research. In August 1922, during his studies at Zhytomyr Higher Pedagogical Courses named after Drahomanov Nykanor Dmytruk received an individual research task from V. Kravchenko, who organized an ethnographic group for students. Nykanor Dmytruk went to the village Trokovychi to gather data about the Chumaks and pottery. A similar task he also got in September 1923. The ethnographic group headed by Vasil Kravchenko issuedah and written magazine "The Ethnographer» (14 issues of the magazine appeared in 1922-1924), where Nykanor Dmytruk presented his research (Dmytruk, 1990, p. 68-69). 
INTERMARUM: history, policy, culture. - Issue 6.

In 1925, Nykanor Dmytruk started collaborating with the Ethnographic Commission of the All-Ukrainian Academy of Sciences (but Volodymyr Bily, the Head of the Commission, pointed that this cooperation began in 1923) (IASFE named after M. T. Rylsky of NAS of Ukraine. F. 1-2. D. 58. L. 86). In February, 1925, Nykanor Dmytruk and Klyment Kvitka (Lesya Ukrainka's husband) were sent by the Ethnographic Commission of the All-Ukrainian Academy of Sciences to collect ethnographic materials in Zhytomyr County. At the same Nykanor Dmytruk carried out the ethnographic research outside Zhytomyr County. He was authorized by the Music Society named after Leontovych to gather data about the contemporary folk music in Kyiv and its suburbs in summer 1925 (ZhMLH. RM. 5656/1-34. L. 32).

After suspending studies because of the liquidation of the Kyiv Archeological Institute in 1925-1928, Nykanor Dmytruk started working as the head of the Department of worker and peasant correspondents of the Soviet press and life of workers in Korosten. He also wrote for the newspapers «The Novye Selo» (Korosten) and «The Robitnyk» (Zhytomyr) (IASFE named after M. T. Rylsky of NAS of Ukraine. F. 1-2. D. 58. L. 86). For some time, Nykanor Dmytruk worked in the Korosten Museum of and conducted ethnographic research of the settlements in the region. These materials became the basis for his first periodicals, in particular in the magazine «The Ethnographic Bulletin», 1925 (Muzychenko, 1990, p. 61).

In 1926, Nykanor Dmytruk sent a letter to Victor Petrov, the Head of the Ethnographic Commission of the All-Ukrainian Academy of Sciences, with a questionnaire designed for collecting materials on the famine in Ukraine, 1921. The program included 17 questions relating to social and economic problems of the post-revolutionary villages, national customs, beliefs, legends, and retellings about the famine in 1921. Stepan Muzychenko noticed:

"He was practically the only one of the contemporary ethnographers, who came to the conclusion about the artificial class divide of the Polissya peasantry, created by the military communism politics and brought up by the ideologists up to the level of the driving force of social development. The poor harvest and deformed class policy in the village resulted in the famine in the early 1920 s, caused by 
IНТЕРМАРУМ: історія, політика, культура. - Вип. 6.

the confiscation of bread from the majority of the rural population" (Muzychenko, 1990, pp. 61-62).

Nykanor Dmytruk's active research in Korosten was highly appreciated by the scholars. Thus, in 1927 at the invitation of the Ethnographic Commission of the All-Ukrainian Academy of Sciences, the ethnographer together with Viktor Petrov, Volodymyr Bily, Mykhaylo Tarasenko and others examined pilotage in the area of the Dnipro hydroelectric power station construction. The research materials from this expedition became the basis for the collection «Materials for the Study of Industrial Associations: the Dnipro Pilots», which was published in 1929 (Andrieiev, 2012, pp. 86-87; Muzychenko, 1990, p. 62). The study of the Dnipro pilotage by the Ethnographic Commission of the All-Ukrainian Academy of Sciences was motivated by several reasons. Firstly, at that time the construction of the Dnipro hydroelectric power station started. The flooding of the Dnieper rapids and the surrounding territories put pilotage at risk of disappearance. Secondly, in the mid-1920s the Ethnographic Commission developed a plan for a thorough examination of the vestiges of the professional associations in Ukraine, including pilotage (Andrieiev, 2012, pp. 85-86).

One of the biggest ethnographic projects conducted by Nykanor Dmytruk was a stationary ethnographic study of the village Didkovychi, Korosten Region, which he started in 1927 and continued with some breaks until 1930. Although the study of Didkovychi was held within the activities of the Ethnographic Commission of the All-Ukrainian Academy of Sciences, we believe that it was initiated personally by Nykanor Dmytruk. At the final stage, in 1930, the scholars from the AllUkrainian Academy of Sciences, Kyiv and Volyn Museum of Local History, and some teachers of the region joined the team of ethnographic study in Didkovychi (IASFE named after M. T. Rylsky of NAS of Ukraine. F. 1-4. D. 219. L. 1-42).

In the late 1920s, the activities of the specialized ethnographic institutions, including the Ethnographic Commission of the AllUkrainian Academy of Sciences, became restricted. The Commission was liquidated in 1933 and some of its members were repressed. On July 11, 1933, in the newspaper "The Communist», the official press media of the Central Committee of the Communist Party in Ukraine, the article entitled «In Captivity of the Class Enemy» appeared. This biased 
INTERMARUM: history, policy, culture. - Issue 6.

ideological publication severely criticized the activities of the Ethnographic Commission of the All-Ukrainian Academy of Sciences, in particular, the collection of articles about the Chumaks (Kostrytsya, 2006, p. 150). Publication of materials about the Chumaks, who traditionally associated with entrepreneurship, freedom, and Ukrainian traditional culture, could not have gone unnoticed by the proponents of the communist values. But the attack against the members of the Ethnographic Commission of the All-Ukrainian Academy of Sciences was rather a reason to start repressions. Consequently, due to the described socio-political conditions, in the late 1920s - early 1930s, Nykanor Dmytruk significantly slowed down his ethnographic activities.

In the late 1920s, Nykanor Dmytruk became a postgraduate student at the Ethnography Department at the Volyn Museum of Local History, headed by Vasyl Kravchenko. "The study of the ethnic minorities in Volyn Region» became one of the priority research areas of the Ethnography Department at the Volyn Museum of Local History in the early 1930s, but Nykanor Dmytruk did not agree with that (IASFE named after M. T. Rylsky of NAS of Ukraine. F. 1-4. D. 219. L. 29, 32 33). It is probably because of that «misunderstanding» in 1930, he temporarily left the work at the Zhytomyr Museum of Local History and moved to Kharkiv, where he later entered the postgraduate study at the Ukrainian Research Institute of Material Culture in the All-Ukrainian Academy of Sciences (State Archives of Zhytomyr Region. F. R-5013. Op. 2. D. 1337. L. 105).

At that time, Nykanor Dmytruk was sent to Moscow and Leningrad (now - St. Petersburg) to work with ethnographic materials in local museums. The People's Commissariat of Education instructed the researcher to prepare materials for the section «Science in Ukraine» in the exhibition «Socialist Building in the Ukrainian SSR». The exhibition was to be held in Moscow (ZhMLH. RM. 5656/1-34. L. 34).

In November 1932, Nykanor Dmytruk received the certificate from the Ukrainian General Directorate of Scientific Institutions at the People's Commissariat of Education of the Ukrainian SSR. The certificate stated that during his postgraduate studies he fulfilled proper theoretical, practical and pedagogical scientific training in his specialty and prepared the thesis «The History of Baraniv Porcelain Factory». 
ІНТЕРМАРУМ: історія, політика, культура. - Вип. 6. ISSN 2518-7694 (Print)

ISSN 2518-7708 (Online)

Nykanor Dmytruk became a Research Fellow (ZhMLH. RM. 5656/134. L. 34).

So, the topic of Nykanor Dmytruk's qualification paper was «The History of Baraniv Porcelain Factory». Today the abstracts of this research entitled «The Study of the History of Baranivka Porcelain» are stored in the funds of the Zhytomyr Museum of Local History (ZhMLH. RM. 5656/1-34. L. 32).

The so-called «Kharkiv period» in Nykanor Dmytruk's activities continued until the end of 1933 when he returned to Zhytomyr (State Archives of Zhytomyr Region F. R-5013. Op. 2. D. 1337. L. 111). In February 1934, the researcher became the Head of the History Department of the Volyn Museum of Local History (ZhMLH. RM. 5656/1-34. L. 35). At that time his research interests included the national minorities in Volyn, in particular, the history of Czech, Jewish, Polish, and German settlements in the region. The emphasis was made on the supposedly «positive» changes in the lives of ethnic minorities after the Bolshevik coup in 1917. For example, in October 1935, Nykanor Dmytruk published an article on the history of the village Kroshnya Czech (now within Zhytomyr) in the newspaper «The Soviet Volyn» (Soviet Volyn. October 28, 1935; Soviet Volyn. October 29, 1935). In the newspaper article from October 29, 1935, he wrote:

"The October Revolution shattered the chains of national oppression and opened up great opportunities for national minorities to have their schools, clubs, reading rooms, where they and their children learn to build a new cultural life" (Soviet Volyn. October 29, 1935).

It is also known that in that period Nykanor Dmytruk worked on the essays about the history of Zhytomyr region (ZhMLH. RM. 5656/134. L. 35). However, the manuscript of this research could not be found.

Since 1925, part of Nykanor Dmytruk's ethnographic research was published in the journal «The Ethnographic Bulletin», for example, the articles «On the Miracles in Ukraine in 1923» (1925, vol. 1, p. 50-61), «From a New Life» (1926, vol. 2, p. 31-37), «The Famine in Ukraine, 1921» (1927, vol. 4, p. 79-87), «Miracles in Poltava Region in 1928» (1928, vol. 8, p. 170-180) (Muzychenko, 1990, p. 61-62). Nykanor Dmytruk also published scientific and journalistic materials in Korosten and Zhytomyr newspapers. 
INTERMARUM: history, policy, culture. - Issue 6.

A number of studies by Nykanor Dmytruk were not published and currently exist in the form of manuscripts. Among them, for example, are the articles «The Harvest» (1923) (IASFE named after M. T. Rylsky of NAS of Ukraine. F. 1-4. D. 210. L. 1-24) and «Something About the Outlaws» (1925) (IASFE named after M. T. Rylsky of NAS of Ukraine. F. 1-4. D. 213. L. 1-9). In the first article, Nykanor Dmytruk provides information on the history of the harvesting customs and rituals of the village Luka, Zhytomyr County, recorded by his mother in July 1923. The goal of the article, according to the ethnographer, was to

"collect exhaustive data about the harvest; the description of all the harvesting works and all the folklore material, but it was only possible to get folklore information, though incomplete" (IASFE named after M. T. Rylsky of NAS of Ukraine. F. 1-4. D. 210. L. 1).

In the second unpublished article «Something About the Outlaws», the researcher analyzes differences between pre-revolutionary and postrevolutionary prisoners' songs «to understand the psychology of the "outlaws" and help the public re-educate prisoners») (Muzychenko, 1990, p. 63).

For a long time, Nykanor Dmytruk's article about Vasyl Kravchenko («45 Years of V. G. Kravchenko’s Ethnographic Research») remained unpublished. The study was issued in the journal «The Folk Art and Ethnography» at the initiative of Stepan Muzychenko in 1990 (Dmytruk, 1990, pp. 64-71). In this article, the researcher presented

“comprehensive factual material about Vasyl Kravchenko's childhood and youth, his formation as a citizen and ethnographer, his scientific and pedagogical activities, ties with such prominent figures of the national culture as O. O. Grushevsky, F. K. Vovk, the writers M. M. Kotsyubinsky, B. D. Grinchenko, T. A. Zinkovsky and others" (Muzychenko, 1990, p. 63).

Until recently «The Monographic Study of Didkovychi Village in Volyn Polissya» was in the form of a manuscript. It was prepared by Nykanor Dmytruk on the results of the ethnographic study of Didkovychi village, Korosten Region, in the framework of the Ethnographic Commission's work in the late 1920s. In this research, in addition to the discussion of the main stages and the results of the ethnographic study of the settlement, Nykanor Dmytruk raises 
IНТЕРМАРУМ: історія, політика, культура. - Вип. 6.

methodological issues of the Soviet ethnography. In particular, he stated:

"...now, in the days of the socialist reconstruction of the village, great changes in the rural life, when the old forms of management, longstanding traditions are disappearing, and the new forms of collective management, socialist life, new revolutionary traditions are coming in their place, the study of the village has become extremely urgent" (IASFE named after M. T. Rylsky of NAS of Ukraine. F. 1-4. D. 219. L. 1).

In addition, Nykanor Dmytruk wrote:

"Soviet ethnography is one of the forms of active participation of the masses in socialism building, in research work and in a comprehensive study of the region to assist the Soviet planning and operational authorities, it is one of the best forms of self-equipment of the masses with the method of scientific analysis" (IASFE named after M. T. Rylsky of NAS of Ukraine. F. 1-4. L. 1).

Could he have written differently at that time? The scholar was aware that without such clarifications his ethnographic studies would not have spread. In 2019, the manuscript «The Monographic Study Didkovychi Village in Volyn Polissya» was issued as a separate print publication by the author of this article (Dmytruk, 2019).

The unpublished and recently published manuscripts of research studies by Nykanor Dmytruk are now stored in the funds of the Institute of Art, Folklore and Ethnology Studies named after M.T. Rylsky in the National Academy of Sciences of Ukraine in Kyiv. Other ethnographic materials collected by the researcher at different times are also kept there. They are an integral part of the collection of materials of the Ethnographic Commission of the All-Ukrainian Academy of Sciences, which was active during $1921-1933$. It should be noted that part of the ethnographic materials collected by Nykanor Dmytruk has been lost. For example, the documentary base of the research on the village Didkovychi (1927), collected by Nykanor Dmytruk and other researchers, is stored not in full (IASFE named after M. T. Rylsky of NAS of Ukraine. F. 1-5. D. 402. L. 2, 20, 22-23, 33-35, 48-59, 67-85, 121, 135-140, 167; IASFE named after M. T. Rylsky of NAS of Ukraine. F. 1-5. D. 403. L. 96). The so-called «standstills», recorded by Nykanor Dmytruk in Didkovychi (1927), are the only best-preserved 
INTERMARUM: history, policy, culture. - Issue 6.

documents (IASFE named after M. T. Rylsky of NAS of Ukraine. F. 15. D. 469. L. 1-62). It is possible that further searches in the archives and museums of Ukraine will reveal previously unknown studies by Nykanor Dmytruk, as well as by other scholars from the Ethnographic Commission of the All-Ukrainian Academy of Sciences, who conducted the ethnographic study of the village Didkovychi.

In 1937, the Stalinist regime strengthened measures to detect and destruct the so-called «enemies of the people». Unfortunately, Nykanor Dmytruk, the Head of the History Department in the Volyn Museum of Local History then, did not avoid that notorious campaign. On September 30, 1937, the article «Who Works at the Zhytomyr Museum?» appeared in the Soviet Volyn newspaper, where the workers of the Museum's History Department were accused of anti-Soviet nationalist activities. The article stated:

"There is practically no department in the Museum left unreached by the dirty hands of this brood, that built a safe dent in the cozy walls of the Museum. But mostly the "nationalist scrapers" hacked up in the History Department. Until recently, the portraits of the sworn enemies of the people were displayed in the most prominent places. In the section where the period of 1917 is to be exhibited, the researcher Snigur hostilely distorted V. I. Lenin's April theses. This "historic exposition" was displayed in the Museum with the blessing of the Head of the History Department N. K. Dmytruk and the Museum Council headed by Lukyanovich" (Kostrytsya, 2006, p. 151; Soviet Volyn. September 30, 1937).

On November 29, 1937, Nykanor Dmytruk was arrested by the People's Commissariat for Internal Affairs. Accused under Articles 5410 and 54-11 of the Criminal Code of the USSR, the researcher was charged with involvement in the «Ukrainian military-rebel nationalist organization» and as its member, since 1936, he «actively worked on organizing the rebel underground with the aim of the armed revolt to overthrow the Soviet regime». Nykanor Dmytruk was also accused of belonging to the anti-Bolshevik Volyn Rebel Army, which he allegedly joined in 1922 (State Archives of Zhytomyr Region. F. R-5013. Op. 2. D. 1337. L. 424). It is likely that Nykanor Dmytruk's accusation of belonging to the Volyn Rebel Army is due to the fact that in spring, 1922, the village Didkovychi, Korosten region, was one of the Army's 
IНТЕРМАРУМ: історія, політика, культура. - Вип. 6.

centers. Earlier, in November 1921, the Volyn group of the Second Winter Campaign of the Army of the Ukrainian People's Republic passed through Didkovychi. And, as noted above, this settlement was the main object of Nykanor Dmytruk's ethnographic research in the late 1920s.

The groundlessness of those accusations was later recognized by the Communist authorities when Nykanor Dmytruk was rehabilitated. The conclusion of the Committee at Zhytomyr region on February 5, 1957, stated:

"From the materials of the case it is not clear what became the reason to arrest the listed people (35 people were involved in the criminal case together with Nykanor Dmytruk) and charge with counterrevolutionary activities because apart from their confessions, received from the accused after the arrest, there is no other objective evidence in the criminal archival case" (State Archives of Zhytomyr Region. F. R-5013. Op. 2. D. 1338. L. 317).

On May 10, 1938, the decision of the three at the Zhytomyr Regional Directorate of the NKVD passed a sentence of the highest punishment. The verdict was performed on June 10, 1938 (State Archives of Zhytomyr Region. F. R-5013. Op. 2. D. 1337. L. 458, 464). Destructed by the communist regime, Nykanor Dmytruk left the wife Olga, who at that time worked as a librarian, and 8-year-old son Yuri (State Archives of Zhytomyr Region. F. R-5013. Op. 2. D. 1336. L. 41opp.). Nykanor Dmytruk was rehabilitated by the resolution of the Military Tribunal of the Pre-Carpathian Military Region (June 19, 1957). According to the resolution, the decision of the Zhytomyr Regional Directorate of the NKVD against Nykanor Dmytruk on May 10, 1938, was canceled and the criminal case against him was terminated in the absence of a crime (State Archives of Zhytomyr Region. F. R-5013. D. 1338. L. 362-363).

Conclusions. Nykanor Dmytruk carried out ethnographic research in the $1920 \mathrm{~s}$ - the late 1930s, and it was largely based on a personal creative initiative of the researcher. He undertook episodic ethnographic studies as a student. After the researcher started collaborating with the Ethnographic Commission of the All-Ukrainian Academy of Sciences, his ethnographic studies became systematic. The ethnographic interests of the scholar included a wide range of issues on the material and 
INTERMARUM: history, policy, culture. - Issue 6.

spiritual culture of the Ukrainian people. Nykanor Dmytruk was also concerned with the ethnographic study of the settlements in Zhytomyr region. Today, part of the scholar's research is in the form of manuscripts, stored in the funds of the Rylsky Institute of Art Studies, Folklore and Ethnology at the National Academy of Sciences of Ukraine in Kyiv. We should also point out that Nykanor Dmytruk was the victim of the Stalinist totalitarian system, aimed at destroying any manifestations of the Ukrainian national life, including free development of ethnography in Ukraine.

\section{BIBLIOGRAPHY}

Andrieiev, V. (2012). V. Petrov Activity in the Ethnography Commission of All Ukrainian Academy of Sciences (1921 - 1933th). Ukrainian Historical Journal, 5, 77-93. [In Ukrainian].

Bekh, M. V. (2012). A Monographic Study of a Village in Ethnology: History and Further Research. Collection of Scientific Works. Series: History and Geography, 45, 35-40. [In Ukrainian].

Dmytruk, N. (1990). 45 years of ethnographic activities of V.G. Kravchenko. Folk Creativity and Ethnography, 3, 64-71. [In Ukrainian].

Dmytruk, N. (2019). The Monographic Study of Didkovychi Village in Volyn Polissya. Zhytomyr: Polissya. 56. [In Ukrainian].

Institute of Arts Studies, Folklore Studies and Ethnology (IASFE) named after M. T. Rylsky of NAS of Ukraine. F. 1-2. D. 58. 1591.

Institute of Arts Studies, Folklore Studies and Ethnology (IASFE) named after M. T. Rylsky of NAS of Ukraine. F. 1-4. D. 210. 241.

Institute of Arts Studies, Folklore Studies and Ethnology (IASFE) named after M. T. Rylsky of NAS of Ukraine. F. 1-4. D. 213. 91.

Institute of Arts Studies, Folklore Studies and Ethnology (IASFE) named after M. T. Rylsky of NAS of Ukraine. F. 1-4. D. 219. 421.

Institute of Arts Studies, Folklore Studies and Ethnology (IASFE) named after M. T. Rylsky of NAS of Ukraine. F. 1-5. D. 402.1791.

Institute of Arts Studies, Folklore Studies and Ethnology (IASFE) named after M. T. Rylsky of NAS of Ukraine. F. 1-5. D. 403. 1391.

Institute of Arts Studies, Folklore Studies and Ethnology (IASFE) named after M. T. Rylsky of NAS of Ukraine. F. 1-5. D. 469. 621. 
IНТЕРМАРУМ: історія, політика, культура. - Вип. 6. ISSN 2518-7694 (Print)

ISSN 2518-7708 (Online)

Kostrytsya, M. (1997). From captivity of oblivion: the ethnographer Nykanor Dmytruk. Great Volyn, 16, 136-138. [In Ukrainian].

Kostrytsya, M. (2006). From the wells of folk art. Rehabbed by history. Zhytomyr region (Vol. 1, 149-153). Zhytomyr: Polissya. [In Ukrainian].

Muzychenko, S. (1990). Introductory article. Dmytruk Nykanor. 45 years of ethnographic activities of V. G. Kravchenko. Folk Creativity and Ethnography, 3, 61-64. [In Russian].

Ruban, O. (2015). Form the ethnographic materials of Nykanor Dmytruk. Folk Creativity and Ethnology, 3, 63-64. [In Ukrainian].

Ryabchykova, F. (2010). Effort of the Ethnographic Department of Volyn' Research Museum (in 1920 through 1931). Extended abstract of Candidate's thesis. Lutsk. 20. [In Ukrainian].

Soviet Volyn. October 28, 1935.

Soviet Volyn. October 29, 1935.

Soviet Volyn. September 30, 1937.

State Archives of Zhytomyr Region. F. R-5013. Op. 2. D. 1336. 2751.

State Archives of Zhytomyr Region. F. R-5013. Op. 2. D. 1337. 5381.

State Archives of Zhytomyr Region. F. R-5013. Op. 2. D. 1338. 3801.

Vasyanovych, O. (2003). Manuscript Funds of the Institute of Art Studies, Folklore and Ethnology as a Source of Folk Meteorology of Ukrainian Polissya. Galicia, 9, 195-197. [In Ukrainian].

Zhytomyr Museum of Local History (ZhMLH). RM. 5656/1-34. 451.

Стельникович Сердій. ЕТНОГРАФІЧНА ДІЯЛЬНІСТЬ НИКАНОРА ДМИТРУКА У 1920-Х-НАПРИКІНЦ 1930-Х РР. Анотація

Метою статті є комплексне вивчення етнографічної діяльності Никанора Дмитрука у 1920-х - наприкінщі 1930-х рр. Методологія наукового дослідження трунтується на основі загальнонаукових $i$ спеціальних історичних методів із врахуванням базових принципів історичного пізнання: історизму, науковості, об'єктивності, системності. Принциии історизму та науковості дозволили відтворити 114 


\section{INTERMARUM: history, policy, culture. - Issue 6. ISSN 2518-7694 (Print) ISSN 2518-7708 (Online)}

етнографічну діяльність Никанора Дмитрука в усій складності та багатоманітності, у взаємозв'язку і взаємозумовленості з тогочасними подіями. Принцип об'єктивності допоміг підійти до розгляду етнографічної діяльності ученого з урахуванням об'єктивних історичних закономірностей, з критичним аналізом літературно-джерельної бази. Принцип системності дозволив сформувати иілісну картину етнографічної діяльності Никанора Дмитрука у 1920-х - наприкіниі 1930х рр. У статті застосовано міждисииплінарний підхід, який реалізований через використання категоріального апарату та науково-дослідного інструментарію інших суспільно-гуманітарних наук. Наукова новизна роботи полягає у тому, що тут уперше на основі широкої джерельної бази комплексно розглянуто етнографічну діяльність Никанора Дмитрука у 1920-х - наприкінці 1930-х рр. У результаті автор приходить до висновку, що Никанор Дмитрук розпочав проводити епізодичні етнографічні дослідження ще будучи студентом. Після початку співпраці Никанора Дмитрука з Етнографічною комісією Всеукрайнської академії наук його етнографічна діяльність набула системного характеру. Об'єктом етнографічних заџікавлень вченого стало широке коло питань, пов'язаних з матеріальною та духовною культурою українського народу. При иьому головну увагу Никанор Дмитрук зосередив на етнографічному вивченні населених пунктів Житомирщини. Його дослідницька робота стала важливим внеском у розвиток етнографічної науки України міжвоєнного періоду.

Ключові слова: Никанор Дмитрук, етнографічне дослідження, Етнографічна комісія Всеукраїнської академії наук, Волинський краєзнавчий музей.

\section{Sergij Stelnykowycz. DZIALALNOŚĆ ETNOGRAFICZNA NYKANORA DMYTRUKA W LATACH 1920-CH - DO KOŃCA 1930-CH}

\section{Streszczenie}

Celem artykułu jest kompleksowe badanie działalności etnograficznej Nykanora Dmytruka w latach 1920-ch - do końca 1930-ch. Metodologia badania opiera się na ogólnych naukowych $i$ specjalnych metodach historycznych, biorac do uwagi podstawowe zasady wiedzy historycznej, czyli historyzmu, naukowości, obiektywizmu, systematyczności. Zasady historyzmu i naukowości umożliwity odtworzenie działalności etnograficznej Nykanora Dmytruka $w$ całej jej kompleksowości $i$ różnorodności, przy warunkach $i w$ powiąaniu $z$ wydarzeniami tamtych czasów. Zasada obiektywności pomogła zbliżyć się do etnograficznej 
IНТЕРМАРУМ: історія, політика, культура. - Вип. 6. ISSN 2518-7694 (Print) ISSN 2518-7708 (Online)

działalności naukowca, biorac do uwagi obiektywne wzorce historyczne, z krytyczna analiza źródła literackiego. Zasada systematyczności pozwolita stworzyć całościowy obraz działalności etnograficznej Nykanora Dmytruka w latach 1920-ch - do końca 1930-ch. W artykule zastosowano podejście interdyscyplinarne, spetnione za pomoca aparatu kategorialnego i narzędzi badawczych innych nauk społecznych $i$ humanistycznych. Oryginalnościa naukowa pracy jest to, że tutaj po raz pierwszy na podstawie szerokiej bazy źródłowej, kompleksowo rozważono działalność etnograficzna Nykanora Dmytruka w latach 1920-ch - do końca 1930-ch. W wyniku autor stwierdza, że Nykanor Dmytruk zacząt prowadzić epizodyczne badania etnograficzne jeszcze kiedy byt studentem. Po rozpoczęciu wspótpracy Nykanora Dmytruka z Komisja Etnograficzna Ogólnoukraińskiej Akademii Nauk jego działalność etnograficzna stała się systematyczna. Przedmiotem etnograficznych zainteresowań naukowca byto szerokie koło pytań zwiazanych z kultura materialna $i$ duchowa narodu ukrainskiego. Jednocześnie główna uwaga Nykanora Dmytruka była przyciagnięta do studiów etnograficznych miejscowości obwodu Żytomierskiego. Jego praca badawcza wniosta istotny wklad w rozwój nauki etnografii Ukrainy w okresie międzywojennym.

Stowa kluczowe: Nykanor Dmytruk, badania etnograficzne, Komisja Etnograficzna Ogólnoukraińskiej Akademii Nauk, Wotyńskie Muzeum Krajoznawcze.

The article was received 09.07.2019 Article recommended for publishing 10.08.2019 